\title{
Syzygium polyanthum (Wight) Walp: A Potential Phytomedicine
}

\author{
Azlini Ismail ${ }^{1 *}$, Wan Amir Nizam Wan Ahmad ${ }^{2}$
}

\section{Azlini Ismail' ${ }^{1}$, Wan Amir Nizam Wan Ahmad²}

'Department of Fundamental Dental and Medical Sciences, Kulliyyah of Dentistry, International Islamic University Malaysia, Kuantan, Pahang, MALAYSIA. 2Biomedicine Program, School of Health Sciences, Health Campus, Universiti Sains Malaysia, Kelantan, MALAYSIA.

Correspondence

Dr. Azlini Ismail

Department of Fundamental Dental and Medical Sciences, Kulliyyah of Dentistry, International Islamic University Malaysia, Kuantan Campus, Indera Mahkota, 25200 Kuantan, Pahang, MALAYSIA.

E-mail: dr_azlini@iium.edu.my

Phone no: +6014-5010081

\section{History}

- Submission Date: 04-09-2018;

- Review completed: 27-11-2018:

- Accepted Date: 19-12-2018

DOI : 10.5530/pj.2019.11.67

Article Available online

http://www.phcogj.com/v11/i2

\section{Copyright}

(C) 2019 Phcog.Net. This is an openaccess article distributed under the terms of the Creative Commons Attribution 4.0 International license.

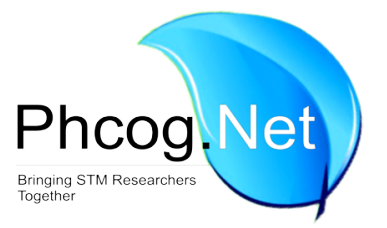

\begin{abstract}
Ethnomedicinal plant is one of the important sources for drug discovery. Syzygium polyanthum (Wight) Walp is one of the ethnomedicinal plants that is currently gaining attention for its various pharmacological potentials. This review evaluates its traditional uses, chemical profiles, toxicological aspects, nutritional values, as well as its pharmacological properties. From our literature search in Science Direct, Scopus, and Google Scholar databases, it was found that S. polyanthum has valuable therapeutic potentials including antidiabetic, antihypertensive, antimicrobial, antioxidant, anticancer, antitumor, antidiarrheal, acetylcholinesterase inhibitory, and dental plaque inhibition properties. However, few research areas, especially its toxicological profiles, mechanism of actions, as well as identification of its bioactive compound, require more in-depth studies.

Keywords: Chemical, Nutritional, Pharmacological, Syzygium polyanthum, Toxicological
\end{abstract}

\section{COMMON NAMES AND PLANT TAXONOMY}

Syzygium polyanthum (Wight) Walp is well known among Malaysians as "salam", "serai kayu”, or "samak kelat", whereas in Indonesia, the plant is commonly recognized as "ubar serai", "meselengan", "manting", Indonesia laurel, or Indonesian bay leaf. ${ }^{1}$ The scientific name $S$. polyanthum was usually used in synonymous with Eugenia polyantha. ${ }^{2}$ According to the Archive of "Catalogue of Life", kingdom, Magnoliophyta phylum, Magnoliopsida class, Myrtales order, Myrtaceae family, Syzygium genus, and S. polyanthum (Wight) Walp species.

\section{TRADITIONAL USES}

Leaves, fruits, and barks of $S$. polyanthum are traditionally used for various medicinal and nonmedicinal purposes. The roots and the fruits are consumed to reverse the hangover effect with alcohol, whereas the leaves are traditionally consumed for treating various illnesses such as diabetes mellitus, hypertension, gastritis, ulcers, diarrhea, skin diseases, as well as infections. ${ }^{4,5}$ People in Riau, Sumatra, Indonesia, has reported to add $S$. polyanthum leaves as one of the ingredients in their soups, and it was consumed for treating hypertension. ${ }^{6}$ Another alternative way of preparing remedies from $S$. polyanthum leaves is by preparing leaf decoction, usually by boiling few pieces of S. polyanthum leaves in plain water until they become concentrated.

Apart from its medicinal use, the young shoots of S. polyanthum are consumed in its raw form as salad, or locally known among Malay as "ulam" and, sometimes, the mature leaves are used to enhance flavor in various local Malay dishes. Until now, it has been recognized as one of the well-known culinary additives in Indonesia. ${ }^{7}$ Besides the leaves, the ripe or unripe fruits of this plant are edible, and the taste is usually described as "sweet-sour." The fruits can be harvested during fruiting season between April and June in the northeastern part of Thailand. ${ }^{8}$ Other than the leaves and fruits, barks of $S$. polyanthum can be used to dye nets in order to enhance their strength.

\section{PLANT DISTRIBUTION}

S. polyanthum is distributed in South-East Asian countries, including Malaysia, ${ }^{9}$ Thailand, ${ }^{8}$ Indonesia, ${ }^{4,5}$ and Singapore. ${ }^{10}$ The plant can be found on hilly areas and in the forests. However, in certain rural areas, the plant is planted in the field and garden, near to the residential area.

\section{PLANT MORPHOLOGY}

The plant's height may reach up to $25 \mathrm{~m}$. The root is straight and the trunk is rounded with lush branch [Figure 1a]. The leaf shape is elliptical with length ranging from 5 to $15 \mathrm{~cm}$ and width ranging from 3 to $8 \mathrm{~cm}$ [Figure 1b]. The base and the end of the leaf are pointy. The upper part of the leaf is dark green with lighter green on the lower part. The leaf petiole is about $0.5-1 \mathrm{~cm}$. The white-colored flowers are small with fragrance [Figure 1c]. The fruit is round with a diameter of 8-9 $\mathrm{mm}$. The unripe fruit is green in color [Figure 1d], and the ripe fruit [Figure 1e] is dark red in color. The brown-colored seed is round with a diameter of $1 \mathrm{~mm}$. 


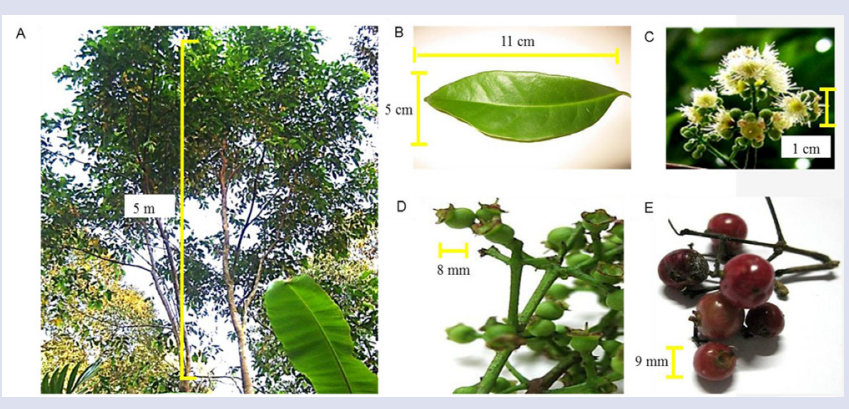

Figure 1: S. polyanthum (Wight.) Walp. (a) whole plant, (b) leaf, (c) flowers, (d) unripe fruits, and (e) ripe fruits

\section{CHEMICAL PROFILES}

Several studies have revealed the phytochemical components of S. polyanthum, but majority of these studies focused on the leaf part of the plant. A preliminary phytochemical screening study conducted by Kusuma et al. ${ }^{11}$ revealed that the leaves and unripe fruits of S. polyanthum contain carbohydrates, tannins, alkaloids, steroids, triterpenoids, and flavonoids, while the ripe fruits contain saponins, carbohydrates, tannins, alkaloids, triterpenoids, and flavonoids. In fact, several studies have quantified the total phenolics and total flavonoids in various types of extracts from barks and leaves of $S$. polyanthum. Lelono et al. ${ }^{4}$ found that methanolic-water extract from $S$. polyanthum bark had the greatest total phenolic content (TPC) in comparison with both methanolic and water extracts, when measured as catechin and gallic acid equivalents. On the contrary, methanolic extract from S. polyanthum bark exhibited the highest total flavonoid content (TFC), when measured as rutin and flavonol equivalents in comparison with methanolic-water and water extracts. When the TPC of $S$. polyanthum leaves was compared with that of $S$. polyanthum barks from previous studies, the TPC of the former ${ }^{12,13}$ was found lower than the latter. ${ }^{4}$

Caffeic acid, gallic acid, ${ }^{13}$ and 4-allyl-1,2-dihydroxybenzene (hydroxychavicol) $)^{2}$ were the three phenolic compounds previously identified in S. polyanthum leaves. Instrumental analyses using highperformance liquid chromatography and liquid chromatography mass spectrometry showed the presence of both caffeic acid and gallic acid in the methanolic extract of $S$. polyanthum leaves $;{ }^{13}$ meanwhile, hydroxychavicol was isolated via bioassay-guided fractionation of ethyl acetate layer from the hydroalcoholic extract of $S$. polyanthum leaves for lipase inhibitory action. ${ }^{2}$ Three hydroxyl benzoic acid derivatives (1) 3,4,5-trihydroxy benzoic acid (gallic acid), (2) 4-hydroxy-3-methoxy benzoic acid, and (3) 4-hydroxy-3,5-dimethoxy benzoic acid were identified from fractionation of the methanol-water extract of $S$. polyanthum leaves. ${ }^{7}$ Compounds 1-3 have basic phenolic structure with benzoic acid moiety; however, only compounds $2-3$ have alpha-glucosidase inhibitory activity, a key enzyme for type 2 diabetes.

Other than that, squalene, a triterpenoid, was detected by using gas chromatography-mass spectrometry analysis on methanol ${ }^{14,15}$ and n-hexane ${ }^{15}$ extracts of $S$. polyanthum leaves. Hamad et al. ${ }^{15}$ have also identified n-hentriacontane, a long chain alkane hydrocarbon, a major volatile compound in n-hexane extract of $S$. polyanthum leaves. Another major compound found in ethanolic extract of $S$. polyanthum leaves is phytol, an acyclic diterpene alcohol. ${ }^{16}$ A recent study by Rahim et al. ${ }^{17}$ also detected the presence of these two compounds (squalene and phytol) in various types of S. polyanthum leaf extracts (n-hexane, ethyl acetate, and methanol). The major composition of these three extracts is sesquiterpenes, but other components such as other types of terpenes (monoterpenes, diterpenes, and triterpenes), phenolics, aldehydes, hydrocarbons, and fatty acids were also identified. The same study also highlighted the presence of some bioactive compounds with varying pharmacological activities such as hentriacontane (anti-inflammatory), palmitic acid (anti-inflammatory and antibacterial), nerolidol (antiinflammatory, antinociceptive, antifungal, and antiulcer), linalool (antibacterial, anti-inflammatory, antidiabetic, and hepatoprotective), a-pinene (anti-inflammatory, antibacterial, and hypotensive), $\alpha$-tocopherol and $\beta$-tocopherol (antioxidant), as well as the two major compounds, squalene (antioxidant, antitumor, and chemopreventive effect), and phytol (anti-inflammatory, anticancer, antimicrobial, antioxidant, and antinociceptive).${ }^{17}$

A latest isolation study by Setyawati et $a .^{18}$ to find skin-whitening compound managed to isolate four compounds from methanolic extract of $S$. polyanthum leaves; the first compound was identified as 1-(2,3,5trihydroxy-4-methylphenyl)hexane-1-one; the second compound was identified as 1-(2,3,5-trihydroxy methylphenyl)octane-1-one; and the third compound was identified as (4E)-1-(2,3,5-trihydroxy-4-methylphenyl)decan-1-one. These three compounds are novel, while the fourth isolated compound was 1-(2,3,5-trihydroxy-4-methylphenyl)decan1-one, a known compound. Compounds 1-4 significantly decreased melanin biosynthesis and were able to inhibit tyrosinase, two important properties for skin whitening.

Other than analysis on the crude extract, there are also ongoing researches on the identification of volatile compounds from the essential oil of $S$. polyanthum leaves. Hydrodistillation of $S$. polyanthum dried leaves produced essential oil with major composition of $\alpha$-pinene, octanal, and a-caryophyllene. ${ }^{19}$ Another recent study had identified few major constituents in the essential oil of S. polyanthum leaves such as cis-4-decanal, 1-decyl aldehyde, and capryl aldehyde. ${ }^{20}$ In addition, few bioactive compounds from terpene group such as $\alpha$-humulene, $\alpha$-copaene, $\alpha$-selinene, $\alpha$-zingiberene, $\beta$-caryophyllene, and caryophyllene oxide were among the identified compounds in the essential oil of this plant. Phytochemical components in the extract and essential oil of $S$. polyanthum leaves are shown in Table 1.

\section{NUTRITIONAL CONTENT}

The nutritional aspect of $S$. polyanthum is also an important aspect to be studied as the leaves are edible and regularly being incorporated in local Malay dishes. Karim et al. ${ }^{21}$ had determined the content of Vitamins (B2, B3, and C) in S. polyanthum leaves. It was found that every $100 \mathrm{mg}$ of dry powder of $S$. polyanthum leaves contains $1.24 \mathrm{mg}$ riboflavin (Vitamin B2), $0.58 \mathrm{mg}$ niacin (Vitamin B3), and $0.40 \mathrm{mg}$ of ascorbic acid (Vitamin C), with the total vitamin content of $2.22 \mathrm{mg} .{ }^{21}$ The human body requires vitamins in trace amount in order to maintain normal physiological functions; therefore, deficiencies of vitamin may lead to various detrimental consequences such as scurvy due to the lack of Vitamin C and pellagra for niacin deficiency.

\section{TOXICOLOGICAL ASPECTS}

Investigation on the toxicological aspect is another integral issue in evaluating the potential of any phytomedicine. Kusuma et al. ${ }^{11}$ previously conducted a cytotoxicity test using brine shrimp (Artemia salina) larvae. The test usually serves as a preliminary assessment assay in evaluating the potential toxicity of a plant extract prior to toxicity evaluation in higher animals. Kusuma et al. ${ }^{11}$ reported that the ethanol extract of S. polyanthum leaves has $\mathrm{LC}_{50}$ (lethal concentration that causes 50\% morbidity in total brine shrimp larvae) of more than $1000 \mu \mathrm{g} / \mathrm{ml}$. An extract was considered as practically nontoxic if the $\mathrm{LC}_{50}$ in brine shrimp lethality test was more than $500 \mu \mathrm{g} / \mathrm{ml} .{ }^{22}$ Therefore, the leaf extract was considered as non- 
Table 1: Phytochemical components in the essential oil and extract of Syzygium polyanthum leaves

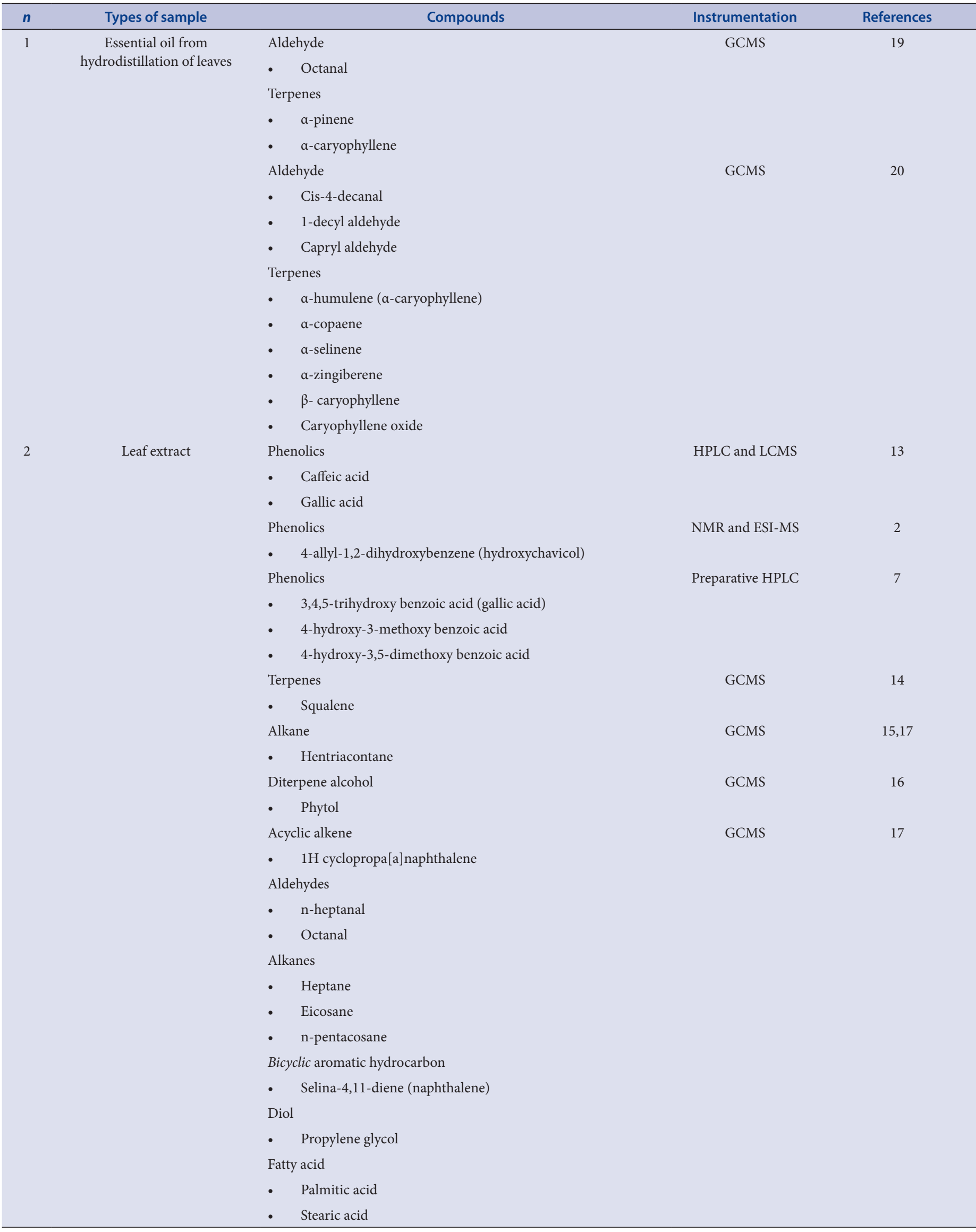


Table 1: Cont'd.

- Hexadecanoic acid, 2-hydroxy-1-(hydroxymethyl) (palmitin)

Fatty acid ester

- Methyl oleate

- Methyl palmitate

Lignan

- 9,12,15-Octadecatrien-1-ol

Methylated phenols (tocopherols)

- $\quad$-tocopherol

- $\quad \beta$-tocopherol

- $\gamma$-tocopherol

Oxygenated terpenes

- Caryophyllene oxide

Peroxides

- Humulene epoxide II

Phenolics

- Pyrogallol

Steroidal

- $\quad \beta$-sitosterol

Saturated terpenoid alkane

- $\quad$ Pentadecane, 2,6,10,14-tetramethyl-

Terpenes

- Azulene

- Farnesol

- a-copaene

- $\delta$-cadinene

- a-cubebene

- a-pinene

- $\alpha$-panasinsene

- $\beta$-panasinsene

- $\quad$-humulene

- $\beta$-selinene

- 2-isopropenyl-4a,8-dimethyl-1,2,3,4,4a,5,6,7octahydronaphthalene ( $\alpha$-selinene)

- Linalool

- Neophytadiene

- Nerolidol

- Valencene

Unclassified

- 2-cyclohexen-3-ol-1-one, 2-[1-iminoethyl]-

- 2,3-dihydro-3,5-dihydroxy-6-methyl-4H-pyran-4-one Unclassified

NMR and MALDI-TOF-MS

- 1-(2,3,5-trihydroxy-4-methylphenyl)hexane-1-one

- 1-(2,3,5-trihydroxy methylphenyl)octane-1-one

- (4E)-1-(2,3,5-trihydroxy-4-methylphenyl)decan-1-one

- $\quad$ 1-(2,3,5-trihydroxy-4-methylphenyl)decan-1-one

GCMS=Gas chromatography mass spectrometry, HPLC=High-performance liquid chromatography, MALDI-TOF-MS=Matrix assisted laser desorption/ionizationtime-of-flight-mass spectrometry, NMR=Nuclear magnetic resonance, ESI-MS=Electron spray ionization-mass spectrometry 
Ismail and Wan Ahmad.: Syzygium polyanthum (Wight) Walp: A Potential Phytomedicine

toxic. The test also indicated the safety of fruits because the study also revealed the $\mathrm{LC}_{50}$ of more than $1000 \mu \mathrm{g} / \mathrm{ml}$ for unripe fruits and 747.45 $\mu \mathrm{g} / \mathrm{ml}$ for ripe fruits. ${ }^{11}$

Perumal et al. ${ }^{12}$ tested the cytotoxicity of $S$. polyanthum leaf extracts on normal Vero cell lines which were derived from the kidney of African green monkeys using 3-(4, 5-dimethylthiazol-2-yl)-2, 5-diphenyltetrazolium bromide (MTT) assay. The colorimetric MTT assay determines the viability of cells reflected by the action of succinate dehydrogenase enzyme on yellow tetrazolium dye, the MTT. The formation of insoluble purple formazan salts indicates the number of viable cells present. This study showed that the inhibitory concentration of $S$. polyanthum leaf extract that caused $50 \%\left(\mathrm{IC}_{50}\right)$ of cytotoxicity of Vero cell lines was $53.50 \mu \mathrm{g} / \mathrm{ml} .^{12}$ Therefore, the extract was noncytotoxic because it has $\mathrm{IC}_{50}$ value of more than $20 \mu \mathrm{g} / \mathrm{ml} .^{23}$ Another MTT assay of methanolic extract of S. polyanthum leaf at a concentration of $25-200 \mu \mathrm{g} / \mathrm{mL}$ has also been tested on B16 melanoma cells for $72 \mathrm{~h} .{ }^{18}$ Even at the highest concentration of $200 \mu \mathrm{g} / \mathrm{mL}$, the methanolic extract of S. polyanthum leaves showed high cell viability.

\section{PHARMACOLOGICAL PROPERTIES}

The pharmacological properties of the ripe and unripe fruits, the barks, and mostly the leaves of $S$. polyanthum were widely studied. Currently, S. polyanthum leaves were reported to have antioxidant, antidiabetic, antimicrobial, antihypertensive, antitumor, antidiarrheal, acetylcholinesterase inhibitory, and lipase inhibitory activities. A summary of these pharmacological properties is outlined in Table 2.

\section{Antioxidant}

Plant is one of the rich sources of antioxidant; it can scavenge free radicals, which is known to contribute in the development of cancer and atherosclerosis by inducing oxidative damage to lipids, proteins, and nucleic acids. Enormous antioxidant studies have been conducted on various parts of $S$. polyanthum including the leaves, the ripe and unripe fruits, as well as the bark. The most commonly employed method was using the diphenyl-1-picrylhydrazyl (DPPH) radical scavenging assay, ${ }^{27-29}$ followed by other methods such as ferric-reducing assay (FRAP), ${ }^{10,26,27}$ beta carotene bleaching assay, ${ }^{7,12,25}$ and 2,2-azino-bis(3-ethylbenzothiozoline-6-sulphonic acid) cation radical scavenging (ABTS) assay. ${ }^{27}$

Majority of antioxidant studies on this plant have focused on the leaf parts which were extracted by using various solvents from various ranges of polarity. Aqueous extract of $S$. polyanthum leaves exhibited relatively high DPPH radical scavenging activity as compared to the other 24 tested plant extracts. ${ }^{10}$ Ethanolic extract of $S$. polyanthum leaves at 50 and $100 \mathrm{ppm}$ exhibited good DPPH radical scavenging activity of $82.00 \%$ and $83.00 \%$, respectively, as compared to $95.00 \%$ radical scavenging activity by ascorbic acid as the reference compound. ${ }^{11} \mathrm{Few}$ other studies reported almost similar values of $\mathrm{EC}_{50}$, for instance, $20.90 \pm 0.26,{ }^{12} 24.09,,^{13}$ and $21.24 \pm 1.14 \mu \mathrm{g} / \mathrm{ml}^{24}$ for methanolic extracts of $S$. polyanthum leaves.

In a few more comprehensive studies that compared the level of antioxidant activity of leaf extracts, methanolic extract has exhibited the strongest DPPH scavenging activity, followed by water, petroleum ether, and chloroform extracts. ${ }^{27}$ Another study has similarly shown that the methanolic extract had the highest antioxidant activity, followed by ethyl acetate, dichloromethane, and hexane extracts. ${ }^{28}$ A latest study also supported this whereby the authors found that methanolic extract has highest antioxidant activities compared to ethyl acetate and hexane extracts. ${ }^{29}$

Other than DPPH assay, the FRAP assay is another common assay to demonstrate the antioxidant activity of an extract/compound. Wong et al. ${ }^{10}$ had shown that aqueous extract of $S$. polyanthum leaves exhibited relatively strong ferric ion-reducing activity as compared to the other 24 tested plant extracts. Later studies compared the ferric ion-reducing activity of different types of S. polyanthum leaf extracts. Ethanolic (50\%) extract of $S$. polyanthum leaves was found to have higher reducing capability compared to water and hexane extract. ${ }^{26}$ In agreement with that, another study using similar assay showed that methanolic extract of $S$. polyanthum leaves had the greatest reducing power followed by water, chloroform, and petroleum ether extract. ${ }^{27}$

The less common antioxidant studies tested for $S$. polyanthum leaf extract were using $\beta$-carotene/linoleic acid bleaching and ABTS assay. Previous researches using $\beta$-carotene/linoleic acid bleaching assay have shown that the methanolic ${ }^{12}$ and water ${ }^{25}$ extracts of $S$. polyanthum leaves exhibited almost similar antioxidant activity as compared to the reference synthetic antioxidant compound, the butylated hydroxytoluene. ${ }^{12,25}$ Similarly, ABTS assay proved that methanolic extract of S. polyanthum leaves also has the highest antioxidant capacity, followed by chloroform extract, water extract, and petroleum ether extract. ${ }^{27}$ Altogether, the findings of DPPH, FRAP, and ABTS assays indicated that the antioxidant compounds of $S$. polyanthum leaves were more concentrated in polar solvents.

Besides leaves, the ripe and unripe fruits of S. polyanthum were also tested and both showed very good antioxidant activity compared to ascorbic acid as the reference compound. ${ }^{11}$ The ripe and unripe fruits of $S$. polyanthum at 100 ppm possess $90.00 \%$ and $88.00 \%$ DPPH radical scavenging activity as compared to $95.00 \% \mathrm{DPPH}$ radical scavenging activity of ascorbic acid. ${ }^{11}$

Not only fruits, but also the bark of this plant was also tested for antioxidant activity. The methanolic, methanolic-water, and the water extracts of $S$. polyanthum bark exhibited DPPH scavenging activity with $\mathrm{EC}_{50}$ value of $0.34 \pm 0.16,0.18 \pm 0.04$, and $0.35 \pm 0.11 \mathrm{mg} / \mathrm{ml}$, respectively. ${ }^{4}$ Meanwhile, by using hydrogen peroxide scavenging method, the methanolic, methanolic-water, and the water extracts of $S$. polyanthum bark exhibited hydrogen peroxide radical scavenging activity of $28.00 \pm 0.54 \%, 15.00 \pm 4.22 \%$, and $74.00 \pm 0.53 \%$, respectively. ${ }^{4}$ In the meantime, by using $\beta$-carotene bleaching assay, the methanolic, methanolic-water, and the water extracts of $S$. polyanthum bark exhibited protection from $\beta$-carotene bleaching with percentages of $76.43 \pm 0.91 \%$, $85.72 \pm 0.57 \%$, and $74.33 \pm 0.53 \%$, respectively. ${ }^{4}$

\section{Antidiabetic}

Diabetes mellitus is one of the most prevailing metabolic disorders with complications such as nephropathy, retinopathy, impotency, stroke, and heart attack. ${ }^{42}$ Patients with diabetes usually suffer from hyperglycemic condition as a consequence of insufficient insulin secretion or excessive glucagon secretion and even insulin resistance. ${ }^{1,7}$ In a preliminary survey conducted among diabetic outpatients attending Health Community Centre Sering in Medan, Indonesia, it was noted that the most commonly used herb as a traditional remedy for diabetes mellitus was S. polyanthum (57.1\%). ${ }^{1}$

An intraperitoneal glucose tolerance test on normal Sprague Dawley (SD) rats has shown that petroleum ether, chloroform and methanolic extracts of S. polyanthum leaves did not significantly alter the normal rat's glucose tolerance. ${ }^{1}$ In an acute hypoglycemic test on nondiabetic rats, administration of methanolic extract of S. polyanthum leaves at dosages from $125 \mathrm{mg} / \mathrm{kg}$ to $1 \mathrm{~g} / \mathrm{kg}$ did not significantly reduce blood glucose level of nondiabetic rats. ${ }^{14}$ However, in both alloxan- ${ }^{7,30}$ and streptozotocin- $^{1}$ induced diabetic rats, S. polyanthum leaf extract was shown to significantly lower blood glucose levels of these two diabetic rat models. Lelono ${ }^{7}$ had shown that 21-day daily treatment with aqueous extract of S. polyanthum leaves at doses of 100,200 , and $300 \mathrm{mg} / \mathrm{kg}$ significantly reduced the blood glucose levels of alloxan-induced diabetic rats. In fact, 
Table 2: Summary of pharmacological activities of Syzygium polyanthum leaves, stem, fruits, and barks

\begin{tabular}{|c|c|c|c|c|c|}
\hline$n$ & Biological activity & $\begin{array}{l}\text { Part of plant } \\
\text { used }\end{array}$ & Solvents & Findings & References \\
\hline \multirow[t]{20}{*}{1} & Antioxidant & Leaf & Water & $\begin{array}{l}\text { DPPH test: Water extract of leaves has relatively high antioxidant activity } \\
\text { reflected by the high scavenging activity as compared to the other } 24 \text { tested } \\
\text { edible plants }\end{array}$ & 10 \\
\hline & & & & $\begin{array}{l}\text { Ferric ion test: Water extract of leaves has relatively strong ferric ion-reducing } \\
\text { activity as compared to the other } 24 \text { tested plants }\end{array}$ & \\
\hline & & & Ethanol & $\begin{array}{l}\text { DPPH test: } 50 \text { and } 100 \mathrm{ppm} \text { of ethanolic extract of leaves exhibited } 82.00 \% \\
\text { and } 83.00 \% \text { of radical scavenging activity as compared to } 95.00 \% \text { radical } \\
\text { scavenging activity by ascorbic acid as a reference compound }\end{array}$ & 11 \\
\hline & & & Methanol & $\begin{array}{l}\text { DPPH test: Methanolic extract of leaves exhibited antioxidant activity with the } \\
\text { EC }_{50} \text { value of } 20.9 \pm 0.26 \mu \mathrm{g} / \mathrm{ml}\end{array}$ & 12 \\
\hline & & & & $\begin{array}{l}\text { Reducing power: Methanolic extract of leaves exhibited reducing power with } \\
\mathrm{EC}_{50} \text { of } 77.55 \pm 0.76 \mu \mathrm{g} / \mathrm{ml}\end{array}$ & \\
\hline & & & & $\begin{array}{l}\boldsymbol{\beta} \text {-carotene/linoleic acid bleaching assay: Methanolic extract of leaves } \\
\text { exhibited greatest inhibition of rates }(91.43 \pm 2.52 \%) \text { almost similar to reference } \\
\text { synthetic antioxidant compound, the BHT with rates of } 92.69 \pm 3.15 \%\end{array}$ & \\
\hline & & & Methanol & $\begin{array}{l}\text { DPPH radical scavenging test: Methanolic extract of leaves have mild } \\
\text { antioxidant activity with } \mathrm{IC}_{50} \text { value of } 24.09 \mu \mathrm{g} / \mathrm{ml} \text { as compared to standard } \\
\text { quercetin with } \mathrm{IC}_{50} \text { value of } 90.85 \mu \mathrm{g} / \mathrm{ml}\end{array}$ & 13 \\
\hline & & & $\begin{array}{l}\text { Methanol and ethyl } \\
\text { acetate }\end{array}$ & $\begin{array}{l}\text { DPPH radical scavenging test: Methanolic extract of leaves has antioxidant } \\
\text { activity with } \mathrm{IC}_{50} \text { value of } 21.24 \pm 1.14 \mu \mathrm{g} / \mathrm{ml} \text {, while the ethyl acetate extract has } \\
\text { lower } \mathrm{IC}_{50} \text { value of } 13.70 \pm 0.24 \mu \mathrm{g} / \mathrm{ml}\end{array}$ & 24 \\
\hline & & & Water & $\begin{array}{l}\boldsymbol{\beta} \text {-carotene/linoleic acid bleaching assay: Water extract of leaves exhibited } \\
\text { almost similar antioxidant activity as compared to the reference synthetic } \\
\text { antioxidant compound, the BHT }\end{array}$ & 25 \\
\hline & & & $\begin{array}{l}\text { Ethanol (50\%), } \\
\text { water, and hexane }\end{array}$ & $\begin{array}{l}\text { FRAP assay: Ethanolic ( } 50 \%) \text { extract of leaves has higher reducing capability } \\
\text { compared to water and hexane extracts }\end{array}$ & 26 \\
\hline & & & $\begin{array}{l}\text { Methanol, water, } \\
\text { petroleum ether, and } \\
\text { chloroform }\end{array}$ & $\begin{array}{l}\text { DPPH radical scavenging test: Methanolic extract of leaves has the highest } \\
\text { antioxidant activity in methanol extract, followed by water, petroleum ether, } \\
\text { and chloroform extracts }\end{array}$ & 27 \\
\hline & & & & $\begin{array}{l}\text { FRAP assay: Methanolic extract of leaves had the greatest reducing power } \\
\text { followed by water, chloroform, and petroleum ether extracts }\end{array}$ & \\
\hline & & & & $\begin{array}{l}\text { ABTS assay: Methanolic extract of leaves also has the highest antioxidant } \\
\text { capacity, followed by chloroform, water, and petroleum ether extracts }\end{array}$ & \\
\hline & & & $\begin{array}{l}\text { Methanol, } \\
\text { ethyl acetate, } \\
\text { dichloromethane, } \\
\text { and hexane }\end{array}$ & $\begin{array}{l}\text { DPPH radical scavenging test: Highest antioxidant activity was observed in } \\
\text { methanolic extract of leaves, followed by ethyl acetate, dichloromethane, and } \\
\text { hexane extracts }\end{array}$ & 28 \\
\hline & & & $\begin{array}{l}\text { Methanol, ethyl } \\
\text { acetate, and hexane }\end{array}$ & $\begin{array}{l}\text { DPPH radical scavenging test: Methanolic extract of leaves has the highest } \\
\text { antioxidant activities compared to ethyl acetate and then hexane extract }\end{array}$ & 29 \\
\hline & & Fruits (ripe) & Ethanol & $\begin{array}{l}\text { DPPH test: Ethanolic extract of ripe fruits at } 50 \text { and } 100 \mathrm{ppm} \text { possesses } \\
88.00 \% \text { and } 90.00 \% \text { radical scavenging activity, respectively, as compared to } \\
95 \% \text { radical scavenging activity by a reference compound, ascorbic acid }\end{array}$ & 11 \\
\hline & & $\begin{array}{l}\text { Fruits } \\
\text { (unripe) }\end{array}$ & Ethanol & $\begin{array}{l}\text { DPPH test: Unripe fruit ethanol extract at } 50 \text { and } 100 \mathrm{ppm} \text { possessed } 84.00 \% \\
\text { and } 88.00 \% \text { radical scavenging activity, as compared to } 95.00 \% \text { radical } \\
\text { scavenging activity by a reference compound, the ascorbic acid }\end{array}$ & 11 \\
\hline & & Bark & $\begin{array}{l}\text { Methanol, } \\
\text { methanol-water and } \\
\text { water }\end{array}$ & $\begin{array}{l}\text { DPPH test: Bark methanol, methanol-water, and water extract exhibited } \\
\text { DPPH scavenging activity with } \mathrm{EC}_{50} \text { value of } 0.34 \pm 0.16 \mathrm{mg} / \mathrm{ml}, 0.18 \pm 0.04 \mathrm{mg} / \\
\mathrm{ml} \text {, and } 0.35 \pm 0.11 \mathrm{mg} / \mathrm{ml}\end{array}$ & 4 \\
\hline & & & & $\begin{array}{l}\text { Hydrogen peroxide radical scavenging activity: Bark methanol, methanolic- } \\
\text { water, and water extracts exhibited activity of } 28.00 \pm 0.54 \%, 15.00 \pm 4.22 \% \text {, and } \\
74.00 \pm 0.53 \% \text {, respectively }\end{array}$ & \\
\hline & & & & $\begin{array}{l}\beta \text {-carotene bleaching assay: Bark methanol, methanol-water, and water } \\
\text { extracts exhibited protection from } \beta \text {-carotene bleaching with percentages of } \\
76.43 \pm 0.91 \%, 85.72 \pm 0.57 \% \text {, and } 74.33 \pm 0.53 \% \text {. }\end{array}$ & \\
\hline
\end{tabular}


Table 2: Cont'd.

\begin{tabular}{|c|c|c|c|c|c|}
\hline \multirow[t]{3}{*}{2} & \multirow[t]{3}{*}{ Anti-diabetic } & \multirow[t]{3}{*}{ Leaf } & $\begin{array}{l}\text { Methanol, } \\
\text { methanol-water and } \\
\text { water }\end{array}$ & $\begin{array}{l}\text { Leaves water extract }(100,200 \text { and } 300 \mathrm{mg} / \mathrm{kg}) \text { significantly reduced blood } \\
\text { glucose levels of alloxan-induced diabetic rats after } 21 \text { days of treatment }\end{array}$ & 7 \\
\hline & & & \multirow[t]{2}{*}{ Methanol } & $\begin{array}{l}\text { Repeated dose (twice daily) administration of the leaves methanol extract at } \\
250,500 \text { and } 1000 \mathrm{mg} / \mathrm{kg} \text { has significantly reduced the fasting blood glucose } \\
\text { levels of streptozocin-induced diabetic rats after } 6 \text { days }\end{array}$ & \multirow[t]{2}{*}{14} \\
\hline & & & & $\begin{array}{l}\text { Leaves methanol extract inhibited glucose absorption from the intestine and } \\
\text { significantly increased glucose uptake in muscle tissue }\end{array}$ & \\
\hline \multirow{3}{*}{3} & \multirow{3}{*}{ Antihypertensive } & \multirow{3}{*}{ Leaf } & \multirow{3}{*}{ Methanol and water } & $\begin{array}{l}\text { Water and methanol leaves extract at concentrations ranging from } 0.1 \text { to } 10 \\
\mathrm{mg} / \mathrm{ml} \text { caused significant vasorelaxation on the isolated thoracic aorta rings } \\
\text { from WKY and SHR }\end{array}$ & \multirow[t]{2}{*}{31} \\
\hline & & & & $\begin{array}{l}\text { Autonomic nervous system receptors with the mediation of nitric oxide was } \\
\text { suggested to be partly involved in causing the vasorelaxation effect }\end{array}$ & \\
\hline & & & & $\begin{array}{l}\text { Single dose of leaves water }(2.50 \text { and } 3.00 \mathrm{~g} / \mathrm{kg}) \text { and methanol }(2.00,2.50 \text { and } \\
3.00 \mathrm{~g} / \mathrm{kg} \text { ) extracts caused significant reduction in blood pressure of SHR rats, } \\
\text { but not in WKY rats when acutely administered }\end{array}$ & 32 \\
\hline \multirow[t]{7}{*}{4} & \multirow{7}{*}{$\begin{array}{l}\text { Anti-microbial } \\
\text { (antibacterial and } \\
\text { antifungal) }\end{array}$} & Leaf and stem & Ethanol & $\begin{array}{l}\text { Leaves and stem ethanol extracts possessed anti-microbial activity against } S \text {. } \\
\text { aureus }\end{array}$ & 34 \\
\hline & & Leaf & Ethanol & $\begin{array}{l}\text { Leaves ethanol extract had antibacterial activity against } S . \text { dysenteriae, a Gram- } \\
\text { negative bacilli, with MBC values in the range of } 10 \%-20 \% \mathrm{w} / \mathrm{v}\end{array}$ & 35 \\
\hline & & Leaf & Essential oil & $\begin{array}{l}\text { Leaves essential oil strongly inhibited B. subtilis growth, but it did not inhibit } \\
\text { E. coli }\end{array}$ & 20 \\
\hline & & Fruit (ripe) & Ethanol & $\begin{array}{l}\text { Ripened fruit ethanol extract showed good activity on } S \text {. typhi, a Gram- } \\
\text { negative, rod-shaped bacterium, in relative to erythromycin as standard }\end{array}$ & 11 \\
\hline & & Leaf & Ethanol & $\begin{array}{l}\text { Ethanol leaves extract exhibited anti-fungal activities against } A \text {. alternata and } \\
\text { C. capsicii }\end{array}$ & 36 \\
\hline & & \multirow{2}{*}{$\begin{array}{l}\text { Leaf and fruit } \\
\text { (ripe and } \\
\text { unripe) }\end{array}$} & \multirow[t]{2}{*}{ Ethanol } & $\begin{array}{l}\text { Leaves, ripe and unripe fruit ethanol extracts at } 40,60 \text { and } 80 \mu \mathrm{g} / \mathrm{disk} \text { had low- } \\
\text { to-moderate activity against } T \text {. mentagrophytes }\end{array}$ & \multirow[t]{2}{*}{11} \\
\hline & & & & $\begin{array}{l}\text { Good activity of the ripe and unripe fruit ethanol extracts }(40,60 \text {, and } 80 \mu \mathrm{g} / \\
\text { disc) was observed against C. albicans }\end{array}$ & \\
\hline \multirow[t]{2}{*}{5} & \multirow[t]{2}{*}{ Antidiarrheal } & \multirow[t]{2}{*}{ Leaf } & \multirow[t]{2}{*}{ Ethanol (70\%) } & $\begin{array}{l}\text { Leaves ethanol extract at } 10,20 \text { and } 30 \% \text { have demonstrated anti-diarrheal } \\
\text { activity when induced by castor oil. This was shown by significant inhibition of } \\
\text { the charcoal transit (marker) as compared to negative control }\end{array}$ & \multirow[t]{2}{*}{37} \\
\hline & & & & $\begin{array}{l}\text { The activity of the highest concentration of extract at } 30 \% \text { were similar to that } \\
\text { of reference drug, loperamide hydrochloride at a dose of } 10 \mathrm{ml} / \mathrm{kg}\end{array}$ & \\
\hline
\end{tabular}


Table 2: Cont'd.

\begin{tabular}{|c|c|c|c|c|c|}
\hline & & & & Leaves ethanol extract have antibacterial activity against $S$. dysenteriae & \multirow[t]{2}{*}{35} \\
\hline & & & & $\begin{array}{l}\text { Leaves ethanol extract contains potassium with concentration of } 2054 \mathrm{ppm} \\
(1.03 \% \mathrm{w} / \mathrm{w}) \text { which is beneficial to provide for the associated hypokalemic } \\
\text { condition due to dysentery }\end{array}$ & \\
\hline 6 & Anti-cancer & Leaf & Flavonoid fraction & $\begin{array}{l}\text { Active flavonoid fraction from the leaves possessed anti-proliferative activity } \\
\text { by inducing cell cycle arrest of } H B 4 C 5 \text { at } G_{1} \text { to } S \text { phase, whereas the active } \\
\text { flavonoid fraction stacked the cell cycle at } G_{2} / M \text { phase }\end{array}$ & 38 \\
\hline 7 & Anti-tumour & Leaf & Ethanol & $\begin{array}{l}\text { Leaves ethanol extract completely suppressed expression of the early-antigen } \\
\text { of Epstein-Barr virus which was induced by a tumor promoter, the phorbol } \\
\text { 12-myristate 13-acetate }\end{array}$ & 39 \\
\hline \multirow[t]{2}{*}{8} & \multirow[t]{2}{*}{$\begin{array}{l}\text { Dental plaque } \\
\text { inhibition }\end{array}$} & \multirow[t]{2}{*}{ Leaf } & \multirow[t]{2}{*}{ Water (decoction) } & $\begin{array}{l}\text { Leaves water extract decreased plaque indexes by } 43.1 \pm 4.02 \% \text { when gargled by } \\
\text { a group of patients with fixed orthodontic appliance }\end{array}$ & \multirow[t]{2}{*}{40} \\
\hline & & & & $\begin{array}{l}\text { Treated patients achieved an average hygiene category }(31-50) \text {, an effect which } \\
\text { was comparable to chlorhexidine }(42.1 \pm 4.3 \%) \text { a gold standard of antimicrobial } \\
\text { agent }\end{array}$ & \\
\hline \multirow[t]{2}{*}{9} & \multirow[t]{2}{*}{ Lipid-lowering } & Leaf & Methanol (50\%) & $\begin{array}{l}50 \% \text { aqueous methanol leaves extract showed } 73 \% \text { inhibitory activity at } 2.75 \\
\mathrm{mg} / \mathrm{mL} \text { against porcine pancreatic lipase }\end{array}$ & 2 \\
\hline & & Leaf & Methanol (80\%) & $\begin{array}{l}500 \mu \mathrm{g} / \mathrm{ml} \text { of leaves methanol extract has inhibitory activity on pancreatic } \\
\text { lipase activity by } 43.1 \pm 4.02 \%\end{array}$ & 41 \\
\hline 10 & $\begin{array}{l}\text { Acetylcholin- } \\
\text { esterase inhibitor }\end{array}$ & Leaf & $\begin{array}{l}\text { Methanol and ethyl } \\
\text { acetate }\end{array}$ & $\begin{array}{l}\text { Leaves methanol and ethyl acetate extracts inhibited acetylcholinesterase } \\
\text { activity with the } \mathrm{IC}_{50} \text { values of } 47.30 \pm 3.54 \mu \mathrm{g} / \mathrm{ml} \text { and } 45.10 \pm 8.06 \mu \mathrm{g} / \mathrm{ml} \text {, } \\
\text { respectively, using Ellman colorimetric assay }\end{array}$ & 24 \\
\hline
\end{tabular}

DPPH=2,2-diphenyl-1-picrylhydrazyl, ABTS=2,2-azino-bis(3-ethylbenzothiozoline-6-sulphonic acid), ACE: Angiotensin Converting Enzyme, FRAP=Ferricreducing assay, SHR=Spontaneously hypertensive rats, WKY=Wistar-Kyoto, MBC=Minimum bactericidal concentration, BHT=Butylated hydroxytoluene, $S$. aureus=Staphylococcus aureus, $S$, dysenteriae $=$ Shigella dysenteriae, B. subtilis=Bacillus subtilis, E. coli=Eschericia coli, $S$. typhi=Salmonella typhi, A. alternate $=$ Alternaria alternate, C. capsicii=Colletotrichum capsicii, T. mentagrophytes=Trichophyton mentagrophytes, C. albicans=Candida albicans

the onset for the antidiabetic effect can be seen as early as 7 days of treatment in alloxan-induced diabetic rats when treated with aqueous extract of $S$. polyanthum leaves at $200 \mathrm{mg} / \mathrm{kg} .{ }^{30}$ In a different diabetic rat model, Widyawati et al. ${ }^{1}$ showed that an acute single dose of S. polyanthum methanolic extract at $1 \mathrm{~g} / \mathrm{kg}$ can significantly reduce blood glucose level in streptozocin-induced diabetic rats after $7 \mathrm{~h}$ of treatment. In another experiment that introduced a repeated dose (twice daily) administration of $S$. polyanthum methanolic extract at tested dose from 250,500 , and $1000 \mathrm{mg} / \mathrm{kg}$, there were significant reductions in the fasting blood glucose levels of streptozocin-induced diabetic rats after 6 days. ${ }^{14}$ In fact, the selective antidiabetic effect by $S$. polyanthum leaves only on diabetic rats is one of the noteworthy observations for this plant. There are few suggested mechanisms of antidiabetic action by S. polyanthum leaf extract. This includes (i) inhibiting alpha-glucosidase, (ii) decreasing glucose absorption, and (iii) increasing glucose uptake by muscle. Alpha-glucosidase is an important enzyme which is responsible for breaking down the large polysaccharides into glucose or sucrose. Inhibition of this enzyme will slow down the time for carbohydrate digestion and thus delays the digestion time. This will lower the rate of glucose absorption. Lelono ${ }^{7}$ showed that methanolwater extract of $S$. polyanthum leaves exhibited the best inhibition of alpha-glucosidase activity as compared to both methanol and water extracts. In fact, this is further supported by a more recent report that showed the ability of methanolic extract of $S$. polyanthum leaves to significantly decrease the intestinal absorption of glucose and to significantly enhance the abdominal muscle tissue uptake of glucose in vitro. ${ }^{14}$ There was also a report that examined the effect of $S$. polyanthum leaf extract in combination with other common antidiabetic plants (Andrographis paniculata). An extract mixture of S. polyanthum and A. paniculata with a ratio of 1:6 displayed largest decrease in blood glucose levels compared to groups treated with single extracts of either S. polyanthum or A. paniculata. ${ }^{30}$ This has indicates for a synergistic effect between the two plants. Andrographolide has been identified as the bioactive antidiabetic compound in A. paniculata. Meanwhile, for S. polyanthum, there were two active compounds (4-hydroxy-3-methoxybenzoic acid and 4-hydroxy-3, 5-dimethoxy-benzoic acid) obtained from bioassay-guided fractionation of the methanolic-water extract of S. polyanthum leaves with inhibitory activity against alpha-glucosidase in vitro.?

\section{Antihypertensive}

One of the pertinent areas that is under ongoing investigations is the antihypertensive effect of this plant. A previous study demonstrated that aqueous and methanolic extracts of $S$. polyanthum leaves significantly lowered blood pressure of normal Wistar-Kyoto (WKY) and spontaneously hypertensive rats (SHR) when the extracts were intravenously administered. ${ }^{9}$ In order to mimic the traditional mode of consumption, a recent study examined the effects of the two extracts when orally gavaged to conscious WKY and SHR rats. ${ }^{32}$ The later study found that an acute administration of aqueous and methanolic leaf extract via oral route significantly lowered the blood pressure of SHR rats, but not in normal WKY.32 In the subsequent subacute study, methanolic leaf extract at a dose of $2.50 \mathrm{~g} / \mathrm{kg}$ when given once on a daily basis caused significant antihypertensive effect in SHR rats; the effect was seen as early as after 2 weeks of administration. In contrast, the antihypertensive effect for the aqueous leaf extract was observed only after 3 weeks of administration. ${ }^{32}$

Recently, the antihypertensive research was extended into the search of its mechanism of action. Studies have shown the possibility of S. polyanthum leaf extract to cause antihypertensive effect via vasorelaxation and by inhibiting angiotensin-converting enzyme (ACE). In vitro study by Ismail and Wan Ahmad ${ }^{31}$ demonstrated significant vasorelaxation effect by aqueous and methanolic extracts of $S$. polyanthum leaves on thoracic aorta rings isolated from WKY and SHR. These researches 
Ismail and Wan Ahmad.: Syzygium polyanthum (Wight) Walp: A Potential Phytomedicine

have also suggested that autonomic receptors and nitric oxide may partly be involved in causing vasorelaxation ${ }^{31}$ and antihypertensive effects. ${ }^{9}$ Other than vasorelaxation, inhibiting ACE, an enzyme important for the conversion of angiotensin I to angiotensin II, was one of the identified mechanisms of antihypertensive action by $S$. polyanthum leaf extract. ${ }^{33}$ Muthia et al. ${ }^{33}$ showed that ethanolic extract of $S$. polyanthum leaves at a concentration of $100 \mathrm{ppm}$ has ACE inhibitory action of $53.37 \pm 0.95 \%$ as compared to standard antihypertensive drug captopril by $88.17 \pm 2.89 \%$.

In addition, in vitro and in vivo studies on rats have shown some significant structural improvement of kidney, an important organ for blood pressure regulation as well as on aorta. Studies have shown that the morphology of kidney and aorta of SHR was significantly ameliorated when daily treated with the methanolic extract of $S$. polyanthum leaves for 4 week $^{43}$ and 6 weeks, ${ }^{44}$ almost comparable to the kidney and aorta of normal WKY rats. Other than that, contractility response to precontractile agent phenylephrine was reduced in the femoral artery of SHR when treated with methanolic extract of S. polyanthum leaves. This finding is important as it is indicative of a less hypersensitive artery. ${ }^{44}$

\section{Antimicrobial}

The high incidence of increased resistance against microorganisms has paved interest into searching alternative antimicrobial therapeutics, especially from plant sources. Extracts from leaves, fruits, as well as essential oil of $S$. polyanthum have been tested with various bacteria and fungi. Ethanolic extracts of $S$. polyanthum leaves and stem have antibacterial activity against Staphylococcus aureus, a Gram-positive, roundshaped bacterium. ${ }^{34}$ Another study has reported that ethanolic extract of S. polyanthum leaves was active against Shigella dysenteriae, a Gramnegative bacillus, with minimum bactericidal concentration values ranging from $10 \%$ to $20 \% \mathrm{w} / \mathrm{v}^{35}$ Essential oil of S. polyanthum leaves strongly inhibited the growth of Bacillus subtilis but not Eschericia coli. ${ }^{20}$ Ripened fruit extract of S. polyanthum showed good activity toward Salmonella typhi, a Gram-negative, rod-shaped bacterium, in relative to erythromycin as standard. ${ }^{11}$

Besides action on bacterium, S. polyanthum have some actions on certain fungi. For instance, ethanolic extract of $S$. polyanthum leaves inhibited the growth of Alternaria alternate and Colletotrichum capsicii using the filter paper disc diffusion technique. ${ }^{36}$ Extracts of $S$. polyanthum leaves and ripe and unripe fruits from 40,60, and $80 \mu \mathrm{g} /$ disc demonstrated antifungal activities, ranging from low to moderate against Trichophyton mentagrophytes, a fungus that causes dermatophytosis. ${ }^{11}$ Good activity of $S$. polyanthum ripe and unripe fruit extracts $(40,60$, and $80 \mu \mathrm{g} / \mathrm{disc})$ was observed against Candida albicans, but not that with $S$. polyanthum leaves. This may suggest the therapeutic potential of $S$. polyanthum ripe and unripe fruit extracts for vaginal yeast infection, skin and diaper rashes, as well diseases caused by Candida. ${ }^{11}$

\section{Antidiarrheal}

Ethanolic extract of S. polyanthum leaves at $10 \%, 20 \%$, and $30 \%$ has demonstrated antidiarrheal activity which was induced by castor oil. ${ }^{37}$ The extracts at these tested concentrations significantly inhibited the transit of charcoal which was used as a marker, as compared to the negative control (carboxymethylcellulose). The activity of the highest concentration of extract which was at $30 \%$ was similar to that of reference drug, loperamide hydrochloride, at a dose of $10 \mathrm{ml} / \mathrm{kg} .{ }^{37}$

Apart from these findings, Fitri et al. ${ }^{35}$ had shown that $S$. polyanthum leaves have antibacterial activity against Shigella dysenteriae, an infective agent that causes shigellosis or bacillary dysentery, an inflammation of the intestines, causing severe diarrhea with the presence of blood or mucus. Another crucial finding was that ethanolic extract of S. polyanthum leaves contains potassium at a concentration of $2054 \mathrm{ppm}(1.03 \% \mathrm{w} / \mathrm{w}){ }^{35}$
This is beneficial to provide for the associated hypokalemic condition due to dysentery. The suggested potassium intake in patients with hypokalemia dysentery is $1170 \mathrm{ppm}$.

\section{Anticancer}

Flavonoid fraction from S. polyanthum leaves was reported to be cytotoxic to mouse colon 26 adenocarcinoma cells and HB4C5 human hybridoma from BALB/c mice. ${ }^{38}$ By using specific assays for apoptosis such as caspase 3-gene expression and annexin-flow cytometry analyses, Sulistiyani et al ${ }^{38}$ suggested that the effect of cell proliferation inhibition was not due to apoptosis; instead of that, the active flavonoid fraction of $S$. polyanthum in fact stacked the cell cycle at $\mathrm{G}_{2} / \mathrm{M}$ phase.

\section{Antitumor}

Ali et al..$^{39}$ had shown that the ethanolic extract of $S$. polyanthum leaves was able to completely suppress the expression of the early antigen of Epstein-Barr virus which was induced by a tumor promoter, the phorbol 12-myristate 13-acetate. Partial suppression by the ethanolic extract of S. polyanthum leaves was observed at low concentrations of 12.5 and $25 \mu \mathrm{g} / \mathrm{ml}$, indicative of a strong antitumor-promoting activity on this plant extract.

\section{Dental plaque inhibition}

S. polyanthum leaves may have some potential usages in dentistry. ${ }^{5}$ Avriliyanti et $a l^{40}$ had shown that aqueous decoction of $S$. polyanthum leaves at a concentration of $60 \%$ has the ability to decrease plaque indexes by $43.1 \pm 4.02 \%$ when the decoction was gargled by a group of patients with fixed orthodontic appliance. These patients have actually achieved an average hygiene category $(31 \%-50 \%)$ in which the effect was comparable to chlorhexidine $(42.1 \pm 4.3 \%)$, a gold standard of antimicrobial agent.

\section{Lipase inhibitory}

Several studies have shown the potential use of $S$. polyanthum leaves in treating and preventing obesity. ${ }^{2,41}$ Kato et al. ${ }^{2}$ showed that $50 \%$ aqueous-methanolic leaf extract at $2.75 \mathrm{mg} / \mathrm{ml}$ showed $73 \%$ inhibitory activity against porcine pancreatic lipase, an enzyme which is important for fat digestion. Hydroxychavicol and another two new dimers have been identified as the active compounds responsible for the lipase inhibitory action by $S$. polyanthum leaves. ${ }^{2}$ Alias et al. ${ }^{41}$ in a recent study on 24 crude plant extracts reported that $S$. polyanthum leaf extract has a medium inhibitory activity of $38.20 \pm 6.50 \%$ against porcine lipase in comparison with the other 23 crude plant extracts. Nevertheless, this finding made this plant interesting to be a part of food additive in the treatment and prevention of obesity.

\section{Acetylcholinesterase inhibitor}

Acetylcholinesterase inhibitor inhibits acetylcholinesterase from cleaving the acetylcholine, thus prolonging the action of acetylcholine at the synaptic junction. Darusman et al..$^{24}$ had shown that the methanolic and the ethyl acetate extracts of $S$. polyanthum leaves inhibited acetylcholinesterase activity with the $\mathrm{IC}_{50}$ values of $47.30 \pm 3.54 \mu \mathrm{g} / \mathrm{ml}$ and $45.10 \pm$ $8.06 \mu \mathrm{g} / \mathrm{ml}$, respectively, using Ellman colorimetric assay. This activity is mainly important for the potential treatment of Alzheimer's disease, a neurodegenerative disorder which is caused by degenerating cholinergic neurons and a decrease in acetylcholine concentration.

\section{Future recommendations}

This review supports the various therapeutic potentials of S. polyanthum. However, there is necessity to extend the research in few areas: (1) to discover the active compounds responsible for these therapeutic effects, 
(2) to study the mechanism of its action, and (3) to comprehensively evaluate its toxicological aspects.

\section{CONFLICTS OF INTEREST}

There are no conflicts of interest.

\section{ACKNOWLEDGMENT}

The study was supported by the Research Initiative Grant Scheme (RIGS15-039-0039) from International Islamic University Malaysia.

\section{Financial support and sponsorship}

The study was supported by the Research Initiative Grant Scheme (RIGS15-039-0039) from International Islamic University Malaysia.

\section{REFERENCES}

1. Widyawati T, Purnawan WW, Atangwho IJ, Yusoff NA, Ahmad M, Asmawi MZ Anti-diabetic activity of Syzygium polyanthum (Wight) leaf extract, the most commonly used herb among diabetic patients in Medan, North Sumatera, Indonesia. Int J Pharm Sci Res 2015;6:1698.

2. Kato $E$, Nakagomi R, Gunawan-Puteri MD, Kawabata J. Identification of hydroxychavicol and its dimers, the lipase inhibitors contained in the Indonesian spice, Eugenia polyantha. Food Chem 2013;136:1239-42.

3. Roskov Y, Kunze T, Paglinawan L, Orrell T, Nicolson D, Culham A, et al. Catalogue of Life 2013 Annual Checklist; 2013. Available from: http://www.catalogueoflife. org/annual-checklist/2013/. [Last accessed on 2015 May 11].

4. Lelono RA, Tachibana S, Itoh K. In vitro antioxidative activities and polyphenol content of Eugenia polyantha wight grown in Indonesia. Pak J Biol Sc 2009;12:1564-70.

5. Sumono A, Wulan AS. The use of bay leaf (Eugenia polyantha wight) in dentistry. Dent J 2008;41:147-50.

6. Grosvenor PW, Gothard PK, McWilliam NC, Supriono A, Gray DO. Medicinal plants from Riau province, Sumatra, Indonesia. Part 1: Uses. J Ethnopharmacol 1995;45:75-95.

7. Lelono RA. Extracts as inhibitors of key enzymes for type 2 diabetes. J Med Sci 2013;13:103-10.

8. Suksri S, Premcharoen S, Thawatphan C, Sangthongprow S. Ethnobotany in bung khong long non-hunting area, Northeast Thailand. Kasetsart J (Nat Sci) 2005;39:519-33.

9. Ismail A, Mohamed M, Sulaiman SA, Wan Ahmad WA. Autonomic nervous system mediates the hypotensive effects of aqueous and residual methanolic extracts of Syzygium polyanthum (Wight) walp. Var. Polyanthum leaves in anaesthetized rats. Evid Based Complement Alternat Med 2013;2013:716532.

10. Wong SP, Leong LP, Koh JH. Antioxidant activities of aqueous extracts of selected plants. Food Chem 2006;99:775-83.

11. Kusuma IW, Kuspradini H, Arung ET, Aryani F, Min YH, Kim JS, et al. Biologica activity and phytochemical analysis of three indonesian medicinal plants, Murraya koenigii, Syzygium polyanthum and Zingiber purpurea. J Acupunct Meridian Stud 2011;4:75-9.

12. Perumal S, Mahmud R, Piaru SP, Chai LW, Ramanathan S. Potential antiradical activity and cytotoxicity assessment of Ziziphus mauritiana and Syzygium polyanthum. Int J Pharmacol 2012;8:535-41.

13. Har LW, Ismail IS. Antioxidant activity, total phenolics and total flavonoids of Syzygium polyanthum (Wight) walp leaves. Int J Med Aromat Plants 2012;2:219-28.

14. Widyawati T, Yusoff NA, Asmawi MZ, Ahmad M. Antihyperglycemic effect of methanol extract of Syzygium polyanthum (Wight.) leaf in streptozotocininduced diabetic rats. Nutrients 2015;7:7764-80.

15. Hamad A, Mahardika MG, Istifah I, Hartanti D. Antimicrobial and volatile compounds study of four spices commonly used in Indonesian culinary. J Food Pharm Sci 2016;4:1-5.

16. Wahjuni S, Wita IW. Hypoglycemic and antioxidant effects of Syzygium polyanthum leaves extract on alloxan induced hyperglycemic wistar rats. Bali Med J 2017;3:113-6.

17. Rahim EN, Ismail A, Omar MN, Rahmat UN, Ahmad WA. GC-MS analysis of phytochemical compounds in Syzygium polyanthum leaves extracted using ultrasound-assisted method. Pharmacogn J 2018;10:110-9.

18. Setyawati A, Hirabayashi K, Yamauchi K, Hattori H, Mitsunaga T, Batubara I, et al. Melanogenesis inhibitory activity of components from Salam leaf (Syzygium polyanthum) extract. J Nat Med 2018; 72(2):1-7.
19. Nur Amalina A, Natanamurugaraj G, Mashitah M, Nurul Ashikin A. Chemical composition, antioxidant and antibacterial activities of Syzygium polyanthum (Wight) Walp. essential oils. Open Conf Proc J 2013;4:139.

20. Hamad A, Mahardika M, Yuliani I, Hartanti D. Chemical constituents and antimicrobial activities of essential oils of Syzygium polyanthum and Syzygium aromaticum. Rasayan J Chem 2017;10:564-9.

21. Karim S, Kasthuri L, Nadiatul N. Vitamins and mineral contents of ten selected weeds and local plants of Kelantan, Malaysia. Int J Biol Pharm Allied Sci 2017;6:161-74.

22. Moshi MJ, Innocent E, Magadula JJ, Otieno DF, Weisheit A, Mbabazi PK, et al. Brine shrimp toxicity of some plants used as traditional medicines in Kagera region, North Western Tanzania. Tanzan J Health Res 2010;12:63-7.

23. Kuete V, Krusche B, Youns M, Voukeng I, Fankam AG, Tankeo S, et al. Cytotoxicity of some Cameroonian spices and selected medicinal plant extracts. J Ethnopharmacol 2011;134:803-12.

24. Darusman LK, Wahyuni WT, Alwi F. Acetylcholinesterase inhibition and antioxidant activity of Syzygium cumini, S. aromaticum and S. polyanthum from Indonesia. J Biol Sci 2013;13:412-6.

25. Othman A, Mukhtar NJ, Ismail NS, Chang SK. Phenolics, flavonoids content and antioxidant activities of 4 Malaysian herbal plants. Int Food Res J 2014;21:759-66.

26. Safriani N, Arpi N, Erfiza NM. Potency of curry (Murayya koeniigi) and salam (Eugenia polyantha) leaves as natural antioxidant sources. Pak J Nutr 2015; $14: 131$

27. Widyawati T, Roslan NA, Yusoff NA, Asmawi MZ, Ahmad M. The evaluation of antioxidant and free radical scavenging activities of Eugenia polyantha leaves extracts. Int J Chem Tech Res 2016;9:465-71.

28. Hidayati MD, Ersam T, Shimizu K, Fatmawati S. Antioxidant activity of Syzygium polyanthum wight extracts. Indones J Chem 2017;17:49-53.

29. Ramdhania Z, Insanu M, Gunarti N, Wirasutisna K, Sukrasno S, Hartati R. Antioxidant activity from ten species of Myrtaceae. Asian J Pharm Clin Res 2017; Special Issue (May) :1-7.

30. Widharna RM, Tamayanti WD, Hendriati L, Hamid IS, Widjajakusuma EC. Antidiabetic effect of the aqueous extract mixture of Andrographis paniculata and Syzygium polyanthum Leaf. Eur J Med Plants 2015;6:82.

31. Ismail A, Wan Ahmad WA. Autonomic receptors and nitric-oxide involvements in mediating vasorelaxation effect induced by Syzygium polyanthum leaves extract. Pharmacognosy Res 2017;9:S9-14.

32. Ismail A, Ramli NS, Mohamed M, Wan Ahmad WA. Acute and sub-acute antihypertensive effects of Syzygium polyanthum leaf extracts with determination of gallic acid using HPLC analysis. Pharmacogn J 2018;10:663-71.

33. Muthia R, Suganda A, Sukandar E. Angiotensin-1 converting enzyme (ACE) inhibitory activity of several Indonesian medicinal plants. Res J Pharm Biol Chem Sci 2017;8:192-9.

34. Grosvenor PW, Supriono A, Gray DO. Medicinal plants from Riau province, Sumatra, Indonesia. Part 2: Antibacterial and antifungal activity. J Ethnopharmacol 1995;45:97-111.

35. Fitri S, Ramdhani D, Mustarichie R. Comparative study on activities of anti bacillary dysentry Shigella dysenteriae of Syzygium polyanthum and Dracaena angustifolia leaves ethanol extracts. Asian J Pharm Clin Res 2017;10:348-52.

36. Mohamed S, Saka S, El-Sharkawy SH, Ali AM, Muid S. Antimycotic screening of 58 Malaysian plants against plant pathogens. Pest Sci 1996;47:259-64.

37. Malik A, Ahmad AR. Anti-diarrheal activity of ethanolic extract of bay leaves (Syzygium polyanthum [Wight.] Walp). Int Res J Pharm 2013;4:106-8.

38. Sulistiyani SF, Wahyuni WT, Sugahara T, Tachibana S, Syaefudin. Cellular mechanism of the cytotoxic effect of extracts from Syzygium polyanthum leaves. Am J Drug Discov Dev 2014;4:90-101.

39. Ali AM, Mooi LY, Yih Yih K, Norhanom AW, Mat Saleh K, Lajis NH, et al. Antitumor promoting activity of some Malaysian traditional vegetable (ulam) extracts by immunoblotting analysis of Raji cells. Nat Prod Sci 2000;6:147-50.

40. Avriliyanti F, Suparwitri S, Alhasyimi AA. Rinsing effect of $60 \%$ bay leaf (Syzygium polyanthum wight) aqueous decoction on the accumulation of dental plaque during fixed orthodontic treatment. Dent J 2017;50:1-5.

41. Alias N, Leow T, Ali M, Tajudin A, Salleh A, Rahman R. Anti-obesity potential of selected tropical plants via pancreatic lipase inhibition. Adv Obes Weight Manag Control 2017;6:1-11.

42. Blair M. Diabetes mellitus review. Urol Nurs 2016;36:27-36.

43. Ramli NS, Muhammad NA, Safuan S, Noordin L, Wan Ahmad WAN. Preliminary evaluation on the effect of methanolic extract from Syzygium polyanthum on improvement of hypertensive-renal damage among spontaneous hypertensive rat models. Ann Microsc 2017;16:15-22.

44. Wan AhmadWAN, Jamal N, RahmatU, Ramli NS, Muhammad NA, Noordin L. Evaluation of Syzygium polyanthum leaves methanol extract as antihypertensive agent in rat. Int J Cardiol 2017:249:S10. 